\title{
Translation Techniques of Affective Expressions in Animal Farm Novel into Indonesian Binatangisme ${ }^{1}$
}

\author{
TMA. Kristanto \\ \{kristanto@ustjogja.ac.id\} \\ University of Sarjanawiyata Tamansiswa, Jl. Kusumanegara 157 Yogyakarta, Indonesia
}

\begin{abstract}
This study aims to describe the translation techniques of affective expressions in Animal Farm novel into Indonesian. It employed a descriptive-qualitative approach to describe the phenomena objectively. The research data were affective expressions taken from Animal Farm novel by George Orwell and their Indonesian version entitled Binatangisme. The number of data was 372 expressions comprised of words, phrases, and clauses. The data were analyzed based on theories of translation techniques by Molina and Albir (2002). The findings reported that there were 10 techniques identified. The technique of Amplification was identified 32 times, Borrowing 17 times, Discursive Creation 1 time, Established Equivalent 218 times, Linguistic Amplification 67 times, Literal Translation 6 times, Modulation 80 times, Reduction 38 times, Transposition 138 times and Deletion 9 times. Thus, it can be concluded that Established Equivalent technique is the most frequently applied by the translator while Discursive Creation is the least.
\end{abstract}

Keywords: affective expression, translation techniques, Animal Farm novel, Binatangisme

\section{Introduction}

In general, translation is a process of re-expressing a message in one language, termed source language (SL), with an equivalent message in another language, termed target language (TL). It is as stated by Nida and Taber [1] that translation is a process of reproducing the closest natural equivalent of the SL message in the TL, in which the priority is the meaning after that the language style. Therefore, the equivalence of meaning and language style is crucial in translating a text, especially literary texts which are related to feelings and aesthetics. Besides, translation can be seen as a product. In this sense, translation is a translated text as a result of the translation process.

A language has its system and cultural background which are often different from other languages. Translators should be aware of them when they are translating texts. Realizing it, they would always consider the equivalence of both meaning and structure when transferring a message from SL to TL. Related to the equivalence of meaning and structure, Bassnett [2] asserted that translation is the rendering of a source-language text into the target language to ensure that (1) the surface meaning of the two will be approximately similar and (2) the structure of the source language will be preserved as closely as possible but not so close that the target

${ }^{1}$ This paper is a part of dissertation dealing with the translation of affective expressions in Animal Farm novel into Indonesian organized by the writer for attaining his doctorate in the Faculty of Cultural Sciences of Gadjah Mada University, Yogyakarta, Indonesia. 
language structures will be seriously distorted. Thus, it can be said that in a translation process, the meaning is the priority over language structure. They should provide the same or closest natural equivalent meaning of SL message in TL. Meanwhile, the structure should follow that of TL to result in natural expressions.

Animal Farm novel is a satirical fiction work written by George Orwell during the Second World War and was published on 17 August 1945. It is a form of fable which tells about the life of animals in Manor Farm. The novel was a satirical criticism of an authoritative ruler of the Soviet Union when Stalin was in power in England. It is considered as the masterpiece of the author among his other works, like Burmese days, Dawn and Out in Paris and London, The Road to Wigan Pier, Homage to Catalonia, and 1984. Out of those literary works, Animal Farm novel was able to place its author parallel with other great authors in England or even in the world as it was named one of the 100 best novels in the world in the $20^{\text {th }}$ century by Times Magazine. Besides, in 1996 it won The Hugo Awards Best Novella in the category of the best science fiction novel and again in 2011, it was awarded Prometheus Hall of Fame Awards as the most popular novel. Therefore, the novel has been translated into different languages including Indonesian. It was translated for the first time by Joesoef Sou'yb in 1962 entitled Kisah Sebuah Pertanian Hewan. Then, it has been translated several times into Indonesian by other translators one of them is Mahbub Djunaidi [3] in 1983. At first, it was titled Peternakan Binatang, and later it was changed to Binatangisme. Due to the high interest of the readers, it was reprinted several times up to 2016. Mahbub Djunaidi is also the figure widely known as a great writer, columnist, politician, and translator in Indonesia. Some of his translations are Di kaki Bukit Gunung Sinai, Cakar-Cakar Irving, dan 100 Tokoh Yang Paling Berpengaruh dalam Sejarah. The above reasons motivated the researcher to carry out this study. Other researchers who had previously conducted similar studies are Mojtaba Askari (2014) [4] who focused on studying procedures of translating proper nouns in Animal Farm into Persian and Umar Mono (2015) focusing on strategies in translating cultural words in Animal Farm into Indonesian.

This study is product-oriented research that tried to investigate how the affective expressions in Animal Farm novel were translated into Indonesian. Accordingly, the Animal Farm is considered as the source text (ST) and the translated text Binatangisme is the target text (TT). This study focused on affective expressions as the research object since it is related to the nature of this literary work, which is a satirical fiction novel. Affective expressions are verbal expressions used by the author in narrating the story. As the expressions are related to the dimension of feeling, the translator was required to have a good competence not only in understanding the messages but also in transferring them in TL. Moreover, as this text is a literary work, he should be able to transfer the styles used in ST to give similar style effects in the TT. As stated by Hoed [5], to produce accurate, acceptable, and readable translations, translators should be capable of rhetoric. In this way, the readers will enjoy the story as the translated text reads as if it were not a translation. There are plenty of data of affective expressions in this novel, like tyrannize, evil, admiration, tormentor, depth of character, imperishable pride, fresh lies, and thoroughly frightened. Thus, the translation units in this study are words, phrases, clauses, and sentences that express the author's feelings towards the situations at that time. The feelings represented the attitude of English people tyrannized by the Soviet regime.

In product-oriented translation studies, researchers usually apply a bottom-up approach. They will begin analyzing the translation techniques that will guide them later to find out the translation methods, and finally, they can determine the ideology of translation orientation of 
the translators. The clear distinction between translation strategies and translation techniques is stated by Molina and Albir [6] in which translation strategies are process-oriented while translation techniques are product-oriented. They are instruments used to classify and describe the actual steps taken by translators in each textual micro-unit. This study, therefore, investigated the translation techniques of affective expressions in Animal Farm novel into Indonesian Binatangisme. It tried to find out the translation techniques applied by the translator, described the distribution of the techniques, and described how the techniques were applied by the translator.

\section{Theoretical Review}

\subsection{Affective Expression}

Affective expressions are closely related to affective meanings which are included in the domain of feelings. Quoted from Shipley, Pateda [7] distinguished affective meaning from emotive meaning. Whereas affective meaning is the meaning perceived by listeners or readers as their reaction to particular language use, the emotive meaning is the one perceived by speakers or writers concerning what they think of or feel. Different from Pateda, Leech [8] stated that affective meaning is a sort of meaning which can reflect the personal feeling of speakers, including his/her attitude to the listener or to something he/she is talking about. From this definition, it is clear that affective meaning is the meaning which reflects the personal feeling of the speakers or writers, their attitudes to listeners or readers, or to things they are talking about.

In line with the definition of affective meaning above, affective expressions are expressions of feelings manifested through words, phrases, clauses, and sentences as the reactions of speakers or writers to things they are talking about. This is from which the idea of analyzing affective expressions in Animal Farm novel was translated into Indonesian departed.

In their book entitled The Language of Evaluation: Appraisal in English, Martin dan White [9] explains that speakers or writers' attitudes towards things they are talking about can be seen from their feeling expressions. Further, they divide the feeling into three categories, namely affect, judgment, and appreciation. The affect originates from emotion, judgment from ethics, and appreciation from aesthetics. Into these categories, various expressions of speakers or writers can be classified and then be assessed to figure out their attitudes.

\subsubsection{Affect}

Affect has to do with emotions when someone reacts to behavior, text/process, or phenomena. It is concerned with registering positive and negative feelings. The typology of affect groups emotions into three major sets having to do with un/happiness, in/security, and dis/satisfaction. Each typology can be exemplified with some expressions below.

1. Un/happiness : sad, dislike, miserable, mourn, frustrated/happy, like love, joy, excited, in ecstasy, adore

2. In/security : uneasy, anxious, threatened, shocked, surprised/comfort, confident, together, conveniently

3. Dis/satisfaction: angry, disappointed, bored with, neglected/satisfied, pleased, delighted, impressed, absorbed 
To recognize such expressions, a distinguishing frame that can be used is a relational attributive process with a conscious participant involving the verb feel: \{someone feels affect about something or something makes someone feel affect that...\}.

For example - Dian feels satisfied that she gets a grade A in the exam.

- It makes us surprised that the cat spills the soup.

\subsubsection{Judgment}

The judgment deals with attitudes towards behavior that one admires or criticizes, praises, or condemns. This region of meaning construes one's attitudes to people and the way they behave. In other words, it can be said that Judgement is typically used for evaluating behaviors. Judgments are divided into two, namely Judgements of esteem and Judgement of sanction. Judgments of esteem have to do with 'normality' (how unusual someone is) while Judgement of sanction has to do with 'veracity' (how resolute they are). Judgments of esteem are then subdivided into three social esteem: normality (how special), capacity (how capable), and tenacity (how dependable) whereas Judgements of sanction are subdivided into two social sanctions: veracity (truth) and propriety (ethics). Some examples of the expressions categorized as judgment are shown below.

1. Judgement of esteem:

- Normality : lucky, natural, fashionable, cool, normal, peculiar, obscure, unlucky, old fashioned

- Capacity : powerful, mature, humorous, clever, productive, weak, sick, childish, stupid, foolish, ignorant

- Tenacity : brave, patient, careful, dependable, loyal, cowardly, stubborn, timidly, unreliable

2. Judgment of sanction:

- Veracity : honest, truthful, direct, credible, deceitful, lie, dishonest, deceptive, manipulative

- Propriety : good, ethical, fair, humble, polite, generous, evil, immoral, vanity, rude, greedy

It is important to notice that modality of probability like probably, may, certainly, modality of usuality, like usually, rarely, sometimes, never, and often, and modality of ability/capacity, like can, able, and capable belong to this category. Besides, modulation of obligation, like should, must, have to, and modulation of inclination, like will, shall, and would are classified into Judgement. To identify such expressions, a relational attributive process ascribing attitude to some person's behavior proves helpful: \{It was a judgment of person/for a person to do that and (for person) to do that was judgment.

For examples: - It was polite of you to talk to a stranger in that way.

- For a child to do that like that was dangerous.

\subsubsection{Appreciation}

Appreciation has to do with evaluations of semiotic and natural phenomena, according to how they are valued or not in a given field. So, the expressions of appreciation evaluate things, text/process, or natural phenomena. Appreciation is divided into three, namely Reaction (do things catch our attention; do they please us?), Composition (balance and complexity), and Valuation (how innovative, authentic, timely, etc.). Some typical expressions of this category are exemplified below.

1. Reaction 
- Impact : fascination, lively, remarkable, notable, dry, boring, monotonous, flat, predictable

- Quality : good, beautiful, appealing, splendid, bad, nasty, plain, repulsive, revolting

2. Composition

- Balance : balanced, harmonious, symmetrical, consistent, unbalanced, distorted, irregular

- Complexity : simple, clear, precise, elegant, detailed, extravagant, unclear, plain. simplistic

3. Valuation : deep, profound, innovative, authentic, genuine, conventional, dated, fake, useless

To recognize the expressions of appreciation, they can be diagnosed through a mental process ascribing an attitude to things: \{Person consider something appreciation $\}$ and \{person see something as appreciation $\}$.

For examples: - We consider your new garden wonderful.

- My colleagues see the job as challenging.

\subsubsection{Graduation}

As stated by Martin and White [9], a defining property of all attitudinal meanings is their gradability. It is a general property of values of Affect, Judgement, and Appreciation that they describe greater or lesser degrees of positivity or negativity. In other words, the meanings can be scaled-up (heightened) or scaled-down (lowered). Therefore, they have the potential to be intensified and compared. Some examples of gradable meanings are very sad, very unhappy, full of sorrows, the more skillful, virtually flawless, startlingly original, so pleasant, very pretty, finer, and as pretty. (as exemplified by Martin and White).

The term graduation refers to the property of attitudinal meaning which can be graded as upscaling or down-scaling. The graduation works on two axes as its sub-categories, namely Focus and Force. Focus graduation is the axis of grading according to prototypicality while Force is the axis of grading according to intensity or amount. In this case, Focus can be up-scaling (sharpening) or down-scaling (softening) the experiential categories. The examples of experiential categories (non-attitudinal terms) are a real husband, a true teacher, a genuine leather bag while the examples of down-scaling the categories and up-scaling experiential category are they play football, sort of, they are kind of foolish, and it was a regret of sort. In the above examples, the words true, real, and genuine are used to up-scale or sharpen the degree of the non-attitudinal terms or experiential categories scalable and the words sort of, kind of, and of sort are used to soften the categories that are to characterize the instances a having only marginal membership in the category.

As stated above, Force is the axis of grading according to intensity or amount. Thus, it can be divided into two sub-categories, namely Intensification and Quantification. The Intensifications graduate with respect to Quality and Process. The Quality relates to adjectives in which to show their degrees they are preceded with such isolated modifiers e.g. slightly greedy, relatively greedy, and very greedy; dreadfully poor (non-figurative); dirt poor, ice-cold (figurative) or infused in the lexicons, e.g. contented, happy, and joyous. The Process can be done in similar ways as that of Quality with isolated modifiers, e.g. slightly reduced, greatly reduced (grammatical intensification); move slowly, move rapidly; came out like a jack in a box; wander about like Brown's cows (lexical intensification) or infused in the lexicons, e.g., like, love, 
adore; trickles, flows, gushes (non-figurative); prices inched up, and prices sky-rocketed (figurative).

Quantifications graduate with respect to imprecise reckonings of number, e.g. a few and many, imprecise reckonings of mass or presence, e.g. small, large; thin, thick; light, heavy; dim, and bright and imprecise reckonings of extent in time and space. The Quantification of time and space is measured with respect to proximity, e.g. near, far; recent, and ancient or distribution, e.g. long-lasting, short-term; wide-spread, and sparse.

\subsection{Translation Technique}

Translation techniques are analytical instruments used to classify and describe the actual steps taken by translators in each textual micro-unit. The micro-units meant in this study are words, phrases, clauses, and sentences that convey affective meanings in SL and are translated into TL. These techniques, according to Molina and Albir [6], are distinguished from translation strategies on the ground that they are related to translation products while translation strategies are related to process. Then, they proposed eighteen strategies as described below.

1. Adaptation: to replace an ST cultural element with one from the target culture, e.g., to translate an English term spaghetti into Indonesian as mie ayam or the term telur dadar in Indonesian as omelette in English.

2. Amplification: to add details that are not in the ST by giving information or paraphrasing to make the information explicit, e.g., to translate the degradation of environment in English as penurunan kualitas lingkungan in Indonesian or the word batik as batik, a piece of cloth printed with patterns or ornaments through the process of waxing and coloring in English.

3. Borrowing: to take a word or expression straight from an SL, which can be either pure borrowing (without change), e.g., to translate the English word printer and a term talk show into Indonesian as printer and talk show or naturalized borrowing (with changes to fit the spelling rules and pronunciation in the TL), e.g., irrigation as irigasi in Indonesian.

4. Calque: to translate literally a word or frequently a phrase lexically or structurally, e.g., to translate an English term judicial commission into Indonesian as Komisi Yudisial.

5. Compensation: to introduce an ST element of information or stylistic effect in another place in the TT because it can be reflected in the same place as in ST, e.g., to translate the sentence He found the concept completely unintelligible into Indonesian as Konsep itu sama sekali tak terjangkau oleh pikirannya.

6. Description: to replace a term or expression with a description of its form and function, as in translating the term Tujuhbelasan in Indonesian into English as an annual celebration of Indonesian independence on August 17.

7. Discursive Creation: to establish a temporary equivalence that is totally unpredictable out of context, e.g., to translate a movie title The Passion of Christ into Indonesian as Sengsara Tuhan Yesus.

8. Established Equivalence: to use a term or expression recognized as an equivalent in the TL (by dictionaries or language in use), e.g., to translate two English terms bowl and illegal logging into Indonesian as mangkok and pembalakan liar respectively.

9. Generalization: to use a more general or neutral word or term in the TL, e.g., to translate an English word beer into Indonesian as minuman keras or to translate an Indonesian word becak into English as vehicle.

10. Linguistic Amplification: to add linguistic elements in translating a word or an expression in the TL. It is frequently used in consecutive interpreting and dubbing, as in translating an 
English expression very surprised into Indonesian as kaget seperti mendengar petir di siang hari bolong.

11. Linguistic Compression: to synthesize or simplify linguistic elements in the TL, as in translating an Indonesian expression Saya tidak dapat mengungkapkan besarnya rasa terima kasih saya kepadamu dengan kata-kata into English as Thank a lot. It is in opposition to Linguistic Amplification.

12. Literal Translation: to translate a word or expression word for word (literally). Frequently it follows the word order or structure of TL, as in translating an English sentence It is very dangerous to cross in a busy street into Indonesian as Itu sangat berbahaya menyeberang di jalan yang sangat sibuk.

13. Modulation: to change the point of view, focus, or cognitive category concerning the ST which can be lexical or structural, e.g., to translate a sentence He refused my offer into Indonesian as Dia tidak dapat menerima tawaran saya.

14. Particularization: to translate a word or term in a more precise or concrete one in the TL, e.g., to translate a word vehicle into Indonesian as mobil or a word in Indonesian pakaian as dress in English. It is in opposition to generalization.

15. Reduction: to suppress information in an ST in the TT as it doesn't distort the meaning, e.g., to translate a sentence Niagara river is located in the border between USA and Canada into Indonesian as Niagara terletak diantara Amerika dan Kanada It is in opposition to Amplification.

16. Substitution: to change linguistic elements for paralinguistic ones (intonation, gesture) or vice versa, e.g., to translate the gesture of nodding in Indonesian culture as Yes in English or the Arab gesture of putting one's hand in his heart as Terima kasih in Indonesian or Thank you in English. It is usually used in interpreting.

17. Transposition: to change a grammatical category, like the class of an SL word or/and its unit of a word or expression in TL, e.g., to translate a sentence I have no knowledge about it into Indonesian as Saya tidak tahu tentang hal itu. In the example, the noun knowledge in English changes its category to a verb in Indonesian.

18. Variation: to change linguistic or paralinguistic elements (intonation, gesture) that affect aspects of linguistic variation, including the changes of tone, style, social dialects, geographical dialects, etc. e.g., to introduce or change dialectal indicators for characters when translating for the theater, changes in tone when adapting novels for children, etc.

\section{Research Method}

This research applied a descriptive-qualitative approach. It means that the researcher described the linguistic phenomena dealing with the translation techniques of affective expressions in Animal Farm novel into Indonesian Binatangisme as the ways they are. As stated by Hancock [10], qualitative research is concerned with developing an explanation of social phenomena which helps us to understand the social world in which people live and why things are the way they are. In line with the definition, by this approach the researcher aimed to identify and describe the translation techniques of affection expressions in Animal Farm novel into Indonesian.

The design of this research is an embedded case study as the focus and main objectives of the research had been stated before the data was collected in which all of them were based on the existing theories. The data of this research are affective expressions in the forms of linguistics units, namely words, phrases, clauses, and sentences. The data were obtained from two sources, 
they are Animal Farm novel by George Orwell [11] (1945) as the source text (ST) and the translated version in Indonesian entitled Binatangisme translated by Mahbub Djuanedi [3] (1983) as the target text (TT). The techniques of collecting the data involved content analysis, documentary technique, and library study. Then, the data were analyzed by comparing the translation of affective expressions in TT to those in ST. Here, both similarities and differences in terms of form and meaning were identified mainly based on translation techniques applied in transferring the messages as proposed by Molina and Albir [6]. The application of techniques can be single or in combination with other techniques as Newmark [12] termed double, triple, or quadruple. Finally, the distribution and application of translation techniques were described.

\section{Findings and Discussions}

\subsection{Findings}

Having analyzed the translation equivalents of affective expressions in the ST and TT, the distribution of translation techniques identified can be presented in table 4.1.1 below. As found in their applications, there were some techniques used singly, while some others were used in combination with other techniques.

Table 4.1.1 Distribution of the Application of Translation Techniques

\begin{tabular}{|c|l|c|c|c|c|c|c|}
\hline \multirow{2}{*}{ No. } & \multirow{2}{*}{ Translation Techniques } & \multicolumn{3}{|c|}{ Variants of Translation Techniques } & \multirow{2}{*}{ Quantity } & \multirow{2}{*}{ Percentage } \\
\cline { 2 - 6 } & & Single & Double & Triple & Quadruple & & \\
\hline 1 & Amplification & 7 & 22 & 3 & - & 32 & $5.29 \%$ \\
\hline 2 & Borrowing & 6 & 4 & 3 & 3 & 17 & $2.80 \%$ \\
\hline 3 & Discursive Creation & - & 1 & - & - & 1 & $0.16 \%$ \\
\hline 4 & Established Equivalent & 130 & 74 & 14 & - & 218 & $36.03 \%$ \\
\hline 5 & Linguistic Amplification & 9 & 46 & 10 & 2 & 67 & $11.07 \%$ \\
\hline 6 & Literal Translation & - & 5 & 1 & - & 6 & $0.99 \%$ \\
\hline 7 & Modulation & 16 & 43 & 20 & 1 & 80 & $13.22 \%$ \\
\hline 8 & Reduction & - & 13 & 22 & 3 & 38 & $6.28 \%$ \\
\hline 9 & Transposition & - & 112 & 23 & 3 & 138 & $22.81 \%$ \\
\hline 10 & Omission & 9 & - & - & - & 9 & $1.49 \%$ \\
\hline
\end{tabular}

As shown in table 1 above, there are ten translation techniques identified in the translation of affective expressions in Animal Farm novel into Indonesian Binatangisme. The last technique, Omission, is not the one proposed by Molina and Albir [6]. It is one of the techniques proposed by Ayora and Delisle as cited in Molina and Albir [1] which should be applied here because in analyzing the data, the phenomenon appeared that some affective expressions were not translated or deleted in TT. Then, it is evident from the table that some techniques dominantly used are Established Equivalent which is applied 218 times (36.03\%), Transposition applied 138 times (22.81\%), Modulation applied 80 times (13.22\%), and Linguistic Amplification applied 67 times (11.07\%). Meanwhile, the least frequently applied technique is Creative Discursion which is only identified once $(0.16 \%)$.

Translation techniques are analytical instruments used to identify and describe the actual steps taken by translators in each textual micro-unit. In other words, the techniques describe the results obtained and classify different types of translation solutions. Therefore, this section also 
discusses the ten translation techniques and provides relevant pieces of evidence taken from the data.

\subsubsection{Techniques of Amplification and Transposition}

By this technique, the translator provides details that are not in the ST by giving information or paraphrasing to make the information explicit. Besides, he changes the grammatical category of the SL word or expression in the TL. An example illustrating the use of the paired techniques is shown below.

\begin{tabular}{|c|l|l|}
\hline No. & \multicolumn{1}{|c|}{ Source Text } & \multicolumn{1}{c|}{ Target Text } \\
\hline 1 & $\begin{array}{l}\text { Its owner, Mr. Pilkington, was an } \\
\text { easy-going }{ }^{183} \text { gentleman farmer who } \\
\text { spent most of his time in fishing or } \\
\text { hunting according to the season (page } \\
16)\end{array}$ & $\begin{array}{l}\text { Pemiliknya, tuan Pilkington, seorang } \\
\text { yang tingkah lakunya seenaknya, } \\
\text { gampang-gampangan } \\
\text { sebagian besar waktu memancing atau } \\
\text { berburu, tergantung dari musim apa } \\
\text { (page 40). }\end{array}$ \\
\hline
\end{tabular}

As shown in the example, the adjective easy going is translated into Indonesian as yang tingkah lakunya seenaknya, gampang-gampangan. The detail information tingkah laku and gampanggampangan makes the message explicit. Here, this technique is also applied in combination with Transposition as there is a unit shift from an adjective to an adjective clause.

\subsubsection{Technique of Borrowing}

Using this technique a translator takes a word or expression straight from an SL, which can be either pure borrowing (without change) or naturalized borrowing (with changes to fit the spelling rules and pronunciation in the TL). However, only naturalized borrowings were observed in the data. An illustrative example can be seen below.

\begin{tabular}{|c|l|l|}
\hline No. & \multicolumn{1}{|c|}{ Source Text } & \multicolumn{1}{c|}{ Target Text } \\
\hline 1 & $\begin{array}{l}\text { At the Meetings, Snowball often won } \\
\text { over the majority by his brilliant } t^{210} \\
\text { speeches, but Napoleon was better at } \\
\text { canvassing support for himself in } \\
\text { between times (page 21). }\end{array}$ & $\begin{array}{l}\text { Pada forum "Pertemuan", babi kader } \\
\text { teladan Snowball sering dapat } \\
\text { dukungan suara mayoritas berkat } \\
\text { pidatonya yang brilian }{ }^{210} \text {, tapi babi } \\
\end{array}$ \\
& & $\begin{array}{l}\text { kader teladan Napoleon punya } \\
\text { kelebihan mencari pendukung buat } \\
\text { dirinya di sela-sela antara satu forum } \\
\text { dengan forum lain (page 49). }\end{array}$ \\
\hline
\end{tabular}

As seen in the example above, the adjective brilliant is translated into Indonesian as brilian. It is clear now the technique of borrowing is applied individually in which the adjective brilliant is directly taken to TL by adapting its spelling and pronunciation system to that of TL.

\subsubsection{Techniques of Discursive Creation and Amplification}

These technique are applied by establishing a temporary equivalent that is totally unpredictable out of context and by introducing details that are not formulated in the ST (information or explicative paraphrasing). An example of the application of the two techniques is shown below.

\begin{tabular}{|l|l|l|}
\hline No. & Source Text & Target Text \\
\hline
\end{tabular}




\begin{tabular}{|c|l|l|}
\hline 1 & $\begin{array}{l}\text { In past years Mr. Jones, although a } \\
\text { hard master, had been a capable } \\
\text { farmer, but of late he had fallen on evil } \\
\text { days }{ }^{139} \text { (page 8). }\end{array}$ & $\begin{array}{l}\text { Di tahun-tahun belakangan ini, kendati } \\
\text { tuan Jones seorang pimpinan yang } \\
\text { keras, kendati ia seorang peternak yang } \\
\text { punya kebolehan, tapi akhirnya ia } \\
\text { terjerumus ke dalam rawa-rawa tak } \\
\text { terpuji }^{139} \text { (page 20). }\end{array}$ \\
\hline
\end{tabular}

In the example above, the translator creates a temporary equivalent of the phrase evil days, that is rawa-rawa tak terpuji. In the translation, the equivalent means various kinds of wickedness which has nothing to do with the ST message, evil days. Actually, the phrase is an idiom that means 'the time when someone has to do something difficult or unpleasant'. It seems that the temporary equivalent is made based on the context in which before the idiom it is said that $\mathrm{Mr}$. Jones used to be a capable farmer while in the next sentence it is said that he had, of late, become much disheartened after losing much money in a lawsuit and had taken to much drinking beer and doing foolish things, like feeding animals on crusts of bread soaked in beer. Besides, providing the equivalent using explicative paraphrasing shows that the translator also applies Amplification technique. Thus, the techniques of Discursive Creation and Amplification are used simultaneously in this data.

\subsubsection{Techniques of Established Equivalent and Modulation}

By Established Equivalence a translator uses a term or expression recognized as an equivalent in the TL (by dictionaries or language in use) and by Modulation, he changes the point of view, focus, or cognitive category concerning ST. It is exemplified in the following example.

\begin{tabular}{|c|l|l|}
\hline No. & \multicolumn{1}{|c|}{ Source Text } & \multicolumn{1}{|c|}{ Target Text } \\
\hline 1 & $\begin{array}{l}\text { Snowball was a more vivacious pig } \\
\text { than Napoleon, quicker in speech and } \\
\text { more inventive, but was not considered } \\
\text { to have the same depth of } \text { character }^{116} \\
\text { (page 7). }\end{array}$ & $\begin{array}{l}\text { Sedangkan babi Snowball lebih } \\
\text { periang dibanding Napoleon, banyak } \\
\text { bicaranya, lebih berakal, tapi dianggap } \\
\text { kurang punya } \text { karakter teguh }^{116} \text { (page } \\
\text { 18). }\end{array}$ \\
\hline
\end{tabular}

As observed in the example above, the term depth of character is translated into TL as karakter teguh. It is also the more common expression in TL, especially when the translator changes the point of view, not translating it as kedalaman karakter. The native speakers of English see the quality of one's character in terms of its depth, whereas those of Indonesian see it in terms of its tenacity. So, the technique of Established Equivalent is applied in combination with Modulation.

\subsubsection{Technique of Linguistic Amplification}

The use of this technique can be seen when a translator adds linguistic elements in translating a word or an expression in the TL. It is illustrated in the following example.

\begin{tabular}{|c|l|l|}
\hline No. & \multicolumn{1}{|c|}{ Source Text } & \multicolumn{1}{c|}{ Target Text } \\
\hline 1 & $\begin{array}{l}\text { The potatoes had become soft and } \\
\text { discoloured } \\
\text { edible } \text { (page 32) }\end{array}$ & $\begin{array}{l}\text { Akibatnya, kentang itu menjadi } \\
\text { lembek, menjadi peot-peot, warnanya } \\
\text { jadi berubah }{ }^{265} \text {, dan cuma sebagian } \\
\text { kecil saja yang masih bisa termakan } \\
\text { (page 78) }\end{array}$ \\
\hline
\end{tabular}


In the example above, the expression soft and discolored is not translated literally as lunak dan berubah warnanya. Instead, the translator uses more words than it should be. In this way, it is evident that he applies the technique of Linguistic Amplification.

\subsubsection{Technique of Literal Translation}

The use of this technique can be identified when a translator translates a word or expression word for word (literally). Frequently, it follows the word order or structure of TL. To illustrate the use of this technique, see the following example.

\begin{tabular}{|c|l|l|}
\hline No. & \multicolumn{1}{|c|}{ Source Text } & \multicolumn{1}{c|}{ Target Text } \\
\hline 1 & $\begin{array}{l}\text { Moses, who was Mr. Jones's especial } \\
\text { pet, was a spy and a tale-bearer, but he } \\
\text { was also a clever talker }\end{array}$ & $\begin{array}{l}\text { Moses itu kesayangan tuan Jones, } \\
\text { tugasnya jadi intel dan tukang bual, tapi } \\
\text { ia juga seorang pembicara yang } \\
\text { pandai }^{134} \text { (page 19). }\end{array}$ \\
\hline
\end{tabular}

In the above example, the noun phrase a clever talker is translated literally as seorang pembicara yang pandai. The phrase is translated word by word but it follows the word order of TL. Nevertheless, the translation sounds natural and is, therefore, considered as an established equivalent either. Accordingly, it can be said that both Literal Translation and Established Equivalence are applied here.

\subsubsection{Technique of Modulation}

By this technique, a translator changes the point of view, focus, or cognitive category concerning the ST which can be lexical or structural. The illustration can be seen in the following example.

\begin{tabular}{|l|l|l|}
\hline No. & \multicolumn{1}{|c|}{ Source Text } & \multicolumn{1}{c|}{ Target Text } \\
\hline 1 & $\begin{array}{l}\text { He would put his snout to the ground, } \\
\text { give several deep sniffs, and exclaim in } \\
\text { a terrible voice } 273, \text { "Snowball! He has } \\
\text { been here! (page 34). }\end{array}$ & $\begin{array}{l}\text { Ia hunjamkan ia punya congor ke tanah, } \\
\text { mencium-cium, kemudian menjerit } \\
\text { keras-keras dengan suara bagai petir } 273\end{array}$ \\
"Snowball!! Ia memang kemari! (page \\
83).
\end{tabular}

The example above shows that the noun phrase a terrible voice is translated as dengan suara bagai petir that literally means 'a sound like a thunderbolt'. The figurative meaning the phrase conveys shows the application of Modulation that the translator changes the cognitive category in which the frightening thunderbolt sound is one of the terrible things. The expression suara bagai petir is used to illustrate the condition impressed in the word terrible which means 'very unpleasant; making you feel very unhappy, upset or frightened'.

\subsubsection{Techniques of Reduction and Literal Translation}

The combination of these two techniques is applied when a translator suppresses an ST information item in the TT and simultaneously translates an expression word for word. The application of these two techniques is shown below.

\begin{tabular}{|c|l|l|}
\hline No. & \multicolumn{1}{|c|}{ Source Text } & \multicolumn{1}{c|}{ Target Text } \\
\hline 1 & $\begin{array}{l}\text { And when they heard the gun booming } \\
\text { and saw the green flag fluttering at the } \\
\text { masthead, their hearts swelled with }\end{array}$ & $\begin{array}{l}\text { Apabila mereka dengar senjata } \\
\text { meletup, apabila mereka lihat dengan } \\
\text { kepala mendongak bendera hijau }\end{array}$ \\
\hline
\end{tabular}




\begin{tabular}{|c|c|}
\hline $\begin{array}{l}\text { imperishable pride }{ }^{343} \text {, and the talk } \\
\text { turned always towards the old heroic } \\
\text { days, the expulsion of Jones, the } \\
\text { writing of the Seven Commandments, } \\
\text { the great battles in which the human } \\
\text { invaders had been defeated. (page 55). }\end{array}$ & $\begin{array}{l}\text { berkibar di puncak tiang, kalbu mereka } \\
\text { menggelembung dengan penuh rasa } \\
\text { bangga }{ }^{343} \text {. } \\
\text { Maka pembicaraan pun beralih ke } \\
\text { masa kepahlawanan masa lampau, ke } \\
\text { masa penyerbuan bangsa manusia } \\
\text { dihancur leburkan dan dipatahkan } \\
\text { (page } 134 \text { ) }\end{array}$ \\
\hline
\end{tabular}

In the example above, the translator suppresses the information by reducing the adjective imperishable from the clause. So, the complete clause their hearts swelled with imperishable pride is only translated as kalbu mereka menggelembung dengan penuh rasa bangga that means 'their hearts swelled with pride'. He omits the word imperishable that means 'that will last for a long time or forever' as it will not seriously distort the meaning of the clause in TT. Meanwhile, the rendering of the clause shows that the translator translates it word for word in which the words are translated literally out of context. Therefore, it can be identified that both Reduction and Literal Translation techniques are applied simultaneously.

\subsubsection{Techniques of Transposition and Established Equivalent}

The use of these two techniques can be identified when a translator changes a grammatical category, like class or/and unit of an SL word in TL, and the words translated contextually are recognized as equivalents in TL. The following example illustrates the use of these two techniques simultaneously.

\begin{tabular}{|c|c|c|}
\hline No. & Source Text & Target Text \\
\hline 1 & $\begin{array}{l}\text { This single farm of ours would support } \\
\text { a dozen horses, twenty cows, hundreds } \\
\text { of sheep-and all of them living in a } \\
\text { comfort }^{63} \text { and a dignity } \\
\text { almost beyond our imagining (page } 3 \text { ). }\end{array}$ & $\begin{array}{l}\text { Peternakan kita yang satu ini saja dapat } \\
\text { menjamin selusin kuda, dua puluh sapi, } \\
\text { beratus domba, dan semuanya bisa hidup } \\
\text { nyaman }{ }^{63} \text { dan bermartabat }{ }^{64} \text { yang } \\
\text { melebihi dari apa yang kita bisa } \\
\text { bayangkan (page 6). }\end{array}$ \\
\hline
\end{tabular}

As seen in the above example, the nouns comfort and dignity change the class in the process of translation to adjectives nyaman and bermartabat respectively. As the two words are translated contextually to create natural expressions in TL, another technique called Established Equivalent is also used simultaneously.

\subsubsection{Technique of Omission}

The use of this technique is shown by omitting a word or phrase in ST without giving a corresponding equivalent in TT. An example of the application of this technique can be seen below.

\begin{tabular}{|c|l|l|}
\hline No. & \multicolumn{1}{|c|}{ Source Text } & \multicolumn{1}{c|}{ Target Text } \\
\hline 1 & $\begin{array}{l}\text { The truest happiness, he said, lay in } \\
\text { working hard and living frugally } \\
\text { (page 54). }\end{array}$ & $\begin{array}{l}\text { Kebahagiaan tulen, kata Napoleon, } \\
\text { adalah hidup dengan kerja keras } \\
\text { sekeras-kerasnya }^{337} \text { (page 131). }\end{array}$ \\
\hline
\end{tabular}

In the example above, the equivalent of the word frugally that means 'economically or using as much money or food as is necessary' is not provided in TT. The absence of the equivalent in 
the example has distorted the meaning of the whole sentence as there is important information that is left untranslated.

\subsection{Discussion}

Based on the description of the findings supported by relevant examples above, it can be seen that the translator used various techniques to produce a good translation with natural expressions and high readability. The dominant usage of certain translation techniques including Established Equivalent, Transposition, Modulation, and Linguistic Amplification shows his effort to create a translation that is acceptable by target readers. As can be inferred from the theory [12], the application of certain techniques leads to the methods used by a translator in translating a text or parts of the text, and, in turn, the methods lead to the orientation of the translation. The implication of the translation techniques to the methods and the translation orientation is shown in table 4.2.1 below.

Table 4.2.1 Translation Orientation

\begin{tabular}{|c|c|c|c|c|}
\hline Orientation & Translation Techniques & Frequency & Translation Methods & Ideology \\
\hline \multirow[t]{2}{*}{ Source Language } & Literal Translation & \multirow{2}{*}{$3.63 \%$} & Literal Translation & \multirow{2}{*}{ Foreignization } \\
\hline & Borrowing & & Faithful Translation & \\
\hline \multirow[t]{8}{*}{ Target Language } & Amplification & \multirow{8}{*}{$96.35 \%$} & \multirow{8}{*}{$\begin{array}{l}\text { Communicative } \\
\text { Translation }\end{array}$} & \multirow{8}{*}{ Domestication } \\
\hline & Discursive Creation & & & \\
\hline & Established Equivalent & & & \\
\hline & Linguistic Amplification & & & \\
\hline & Modulation & & & \\
\hline & Reduction & & & \\
\hline & Transposition & & & \\
\hline & Deletion & & & \\
\hline
\end{tabular}

The much higher percentage of the translation techniques oriented to the source language indicates that the translator tried in such a way that the translation is easy to understand by the target readers. Moreover, when the translation of affective expressions in this literary text uses a lot of simple words with some figurative expressions, it makes the Indonesian version of this novel (Binatangisme) more enjoyable.

Affective expressions belong to the domain of feeling. Therefore, they deal with gradable meanings of the adjectives, verbs, and adverbs involved, either as individual words or phrases. The term 'gradable' here means the quality of words which can be up-scaled or down-scaled. As revealed in this study, a great number of the data are gradable, either up-scaling or downscaling, in terms of intensification and quantification. So, on the ground of the two terms, modulation (the shifts of meaning) can be further distinguished into Modulation of Meaning Intensification (MMI) and Modulation of Meaning Quantification (MMQ). Making a clear distinction is necessary to do as in categorizing the data in this research the writer could only use a general term, 'the shift of nuance of meaning'. The term should be made more specific so that it can describe the ST intended meanings more precisely. Some examples of MMI found in the data are so highly regarded, very slowly, thoroughly frightened, and crystal clear, while some examples of MMQ are a little uneasy, mighty shoulders, nearby mountains, and much secret. Realizing the importance of the new translation techniques, their clear definitions should 
be made. Firstly, the technique of Modulation of Meaning Intensification is a technique when a translator scale-up (heighten) or scale-down (lower) the intensity of an ST word in the TT. Secondly, Modulation of Meaning Quantification is a technique when a translator scale-up (heighten) or scale-down (lower) the quantification of an ST word in the TT.

To give a brief description of the implementation of the Modulation of Meaning Intensification, three examples are shown below.

\begin{tabular}{|c|c|c|}
\hline No. & Source Text & Target Text \\
\hline 1 & $\begin{array}{l}\text { Snowball and Napoleon were by far } \\
\text { the most active }{ }^{169} \text { in the debates (page } \\
\text { 13). }\end{array}$ & $\begin{array}{l}\text { Babi kader teladan Snowball dan } \\
\text { Napoleon senantiasa amat aktifl' } \\
\text { dalam perdebatan (page } 33 \text { ). }\end{array}$ \\
\hline 2 & $\begin{array}{l}\text { These two disliked each other so } \\
\text { much }{ }^{186} \text { that it was difficult for them to } \\
\text { come to any agreement, even in } \\
\text { defense of their own interests (page } \\
\text { 16) }\end{array}$ & $\begin{array}{l}\text { Keduanya saling tidak suka, saling } \\
\text { benci, saling gregetan }{ }^{186} \text {, sehingga } \\
\text { mustahil bisa sepakat, kendati untuk } \\
\text { membela kepentingan mereka (page } \\
\text { 40). }\end{array}$ \\
\hline 3 & $\begin{array}{l}\text { Nevertheless, they were both } \\
\text { thoroughly frightened }{ }^{187} \text { by the } \\
\text { rebellion on Animal Farm, and very } \\
\text { anxious }^{188} \text { to prevent their own animals } \\
\text { from learning too much about it (page } \\
\text { 16). }\end{array}$ & $\begin{array}{l}\text { Namun, bagaimana pun juga, keduanya } \\
\text { merasa cemas }{ }^{187} \text { mendengar } \\
\text { pemberontakan di perternakan } \\
\text { "BINATANG", dan bekerja mati- } \\
\text { matian }{ }^{188} \text { mencegah binatang- } \\
\text { binatangnya tahu kelewat banyak } \\
\text { tentang peristiwa itu (page } 40 \text { ). }\end{array}$ \\
\hline
\end{tabular}

In the first example, the superlative form of comparison the most is translated as amat in TL. It is equal to very in SL, though it belongs to a casual variety, which is classified as the comparative form of comparison. This shift of meaning indicates the implementation of Modulation of Meaning Intensification as the ST meaning is down-scaled or lowered in TT. Then, in the second example, the expression so much that functions as an intensifier in SL are translated differently in the form of repetition in TL. The repeated expressions saling tidak suka, saling benci, saling gregetan that means 'dislike each other, hate each other, irritate each other' serves the function as an intensifier that is equal to so much in SL. Thus, the MMI is implemented through this example. Finally, in the third example, there are two examples of MMI shown here. The word thoroughly is not translated in TT while the word very is translated as mati-matian which means 'a serious effort' in TL. The absence of the equivalent of thoroughly that functions as an intensifier distort the ST meaning, whereas the equivalent given to the word very which also serves the function as an intensifier can give a similar meaning. Thus, the implementation of MMI is exemplified in these two words.

Similarly, the implementation of Modulation of Meaning Quantification can be illustrated in the following examples.

\begin{tabular}{|c|l|l|}
\hline No. & \multicolumn{1}{|c|}{ Source Text } & \multicolumn{1}{c|}{ Target Text } \\
\hline 1 & $\begin{array}{l}\text { Clover made a sort of wall round them } \\
\text { with her } \text { great }^{29} \text { foreleg, and the }\end{array}$ & $\begin{array}{l}\text { Si kuda Clover membentuk semacam } \\
\text { dinding dengan kaki depan mereka } \\
\text { yang besar }{ }^{29} \text { itu, sehingga anak-anak }\end{array}$ \\
\hline
\end{tabular}




\begin{tabular}{|c|l|l|}
\hline & $\begin{array}{l}\text { ducklings nestled down inside it and } \\
\text { promptly fell asleep (page 3). }\end{array}$ & $\begin{array}{l}\text { bebek itu meneriap di bagian sebelah } \\
\text { dalamnya, dan segera tertidur (page 3). }\end{array}$ \\
\hline 2 & $\begin{array}{l}\text { Let us face it: our lives are miserable, } \\
\text { laborious, and } \text { short }^{46} \text { (page 3) }\end{array}$ & $\begin{array}{l}\text { Mari kita perhatikan baik-baik: hidup } \\
\text { kita ini sebenarnya menyedihkan. } \\
\text { Hidup kita ini terbebani kelewat banyak } \\
\text { kerja keras. Hidup kita ini sangat } \\
\text { singkat }^{46} \text { (page 5). }\end{array}$ \\
\hline
\end{tabular}

As shown in the first example above, the word great is translated as besar in TL. In SL, the word great is an adjective that means 'very large; much bigger than average in size and quantity' while in TL the corresponding adjective is equal to big that means 'large in size, degree, amount, etc.'. In graduation of meaning, it is called an infused intensification (contrary to separate intensification), in which the intensification is fused in individual words. Accordingly, the translation slightly distorts the ST meaning. Likewise, in the second example, it is shown that the word short is translated as sangat singkat in TL. The meaning of sangat in SL is 'very' and serves the function as a modifier or, specifically, an intensifier in the adjective phrase. So, the phrase means 'very short' in SL. The equivalent made slightly distorts the meaning of the SL word. Therefore, it can be inferred that the two examples show the implementation of the technique of MMQ.

Based on the explanation above, the invention of the two translation techniques, namely Modulation of Meaning Intensification and Modulation of Meaning Quantification, is proposed as additional findings. The two techniques are necessary to be implemented in the translation of words or expressions related to feelings to give adequate equivalents. Another reason is that this important thing is not covered in the Modulation defined by Molina and Albir. Therefore, if the technique of Amplification can be distinguished from Linguistic Amplification and Linguistic Compression, likewise the technique of Modulation can be further distinguished from Modulation of Meaning Intensification and Modulation of Meaning Quantification.

\section{Conclusion}

Based on the finding and discussion above, it can be drawn some conclusions. Firstly, concerning translation techniques, from 372 data there are ten techniques identified in the translation of affective expressions in the Animal Farm novel into Indonesian Binatangisme. The translation techniques are distributed in different variants of application. The techniques may be used singly, doubly, triply, or quadruply. Secondly, there are four dominant techniques applied, namely Established Equivalent which is applied 218 times (36.03\%), Transposition applied 138 times (22.81\%), Modulation applied 80 times (13.22\%), and Linguistic Amplification applied 67 times (11.07\%) from which the most frequently applied technique is Established Equivalent. On the contrary, it is found that the least frequently applied technique is Creative Discursion which is only applied once (0.16\%). Finally, based on the characteristics of data used in this study, it is proposed that there are two techniques of translation, namely Modulation of Meaning Intensification (MMI) and Modulation of Meaning Quantification (MMQ). These two techniques are, hopefully, can be used as additional diagnostic instruments in analyzing data in the form of affective expressions. 


\section{Acknowledgment}

This paper is a part of a dissertation dealing with the translation analysis of Affective Expressions in Animal Farm novel by George Orwell into Indonesian Binatangisme. It is a partial requirement for the attainment of a Doctorate in the Faculty of Cultural Sciences of Gadjah Mada University in which the writer is currently studying. The writer is indebted to both promotor, Mr. Prof. Dr. Syamsul Hadi, S.U., M.A., and co-promotor, Mr. Dr. Adi Sutrisno, M.A., who have generously and patiently encouraged him during his study. Therefore, he would like to express his deepest and sincerest gratitude to them. Besides, he is also indebted to the provider of BPP-DN scholarship which has kindly funded his study. It has also become an important part of the success of his current study to which he owes it a great depth of gratitude.

\section{References}

[1] E. Nida dan C. R. Taber, The Theory and Practice of Translation, Leiden: E.J. Brill, 1969.

[2] S. B. McGuire, Translation Studies, New York: Methuen \& Co.Ltd., 1980.

[3] M. Djunaidi, Binatangisme, Yogyakarta: Gading Publishing, 2016.

[4] M. Askari, "Challenges in Translation of Proper Nouns: A Case Study in Persian Translation of George Orwell's Animal Farm," International Journal of Comparative Literature and Comparative Studies, pp. 19-28, 2014.

[5] B. H. Hoed, Penerjemahan dan Kebudayaan, Bandung: Pustaka Jaya, 2006.

[6] A. Molina dan A. H. Albir, "Translation Techniques Revisited: A Dynamic and Functionalist Approach,” Journal of META, vol. XLVII, no. No. 4, pp. 202-215, 2002.

[7] M. Pateda, Semantik Leksikal, Flores: Nusa Indah, 1986.

[8] G. Leech, Semantics, England: Penguin Books Ltd., 1994.

[9] J. Martin dan P. White, The Labguage of Evaluation, New York: Palgrave McMilan, 2005.

[10] B. Hancock, K. Windridge dan E. Ockleford, An Introduction to Qualitative Research, The NIHR RDS EM /YH, 2007.

[11] G. Orwell, Animal Farm, Internet Edition, 2004.

[12] P. Newmark, A Textbook of Translation, London: Prentice Hall, 1988. 